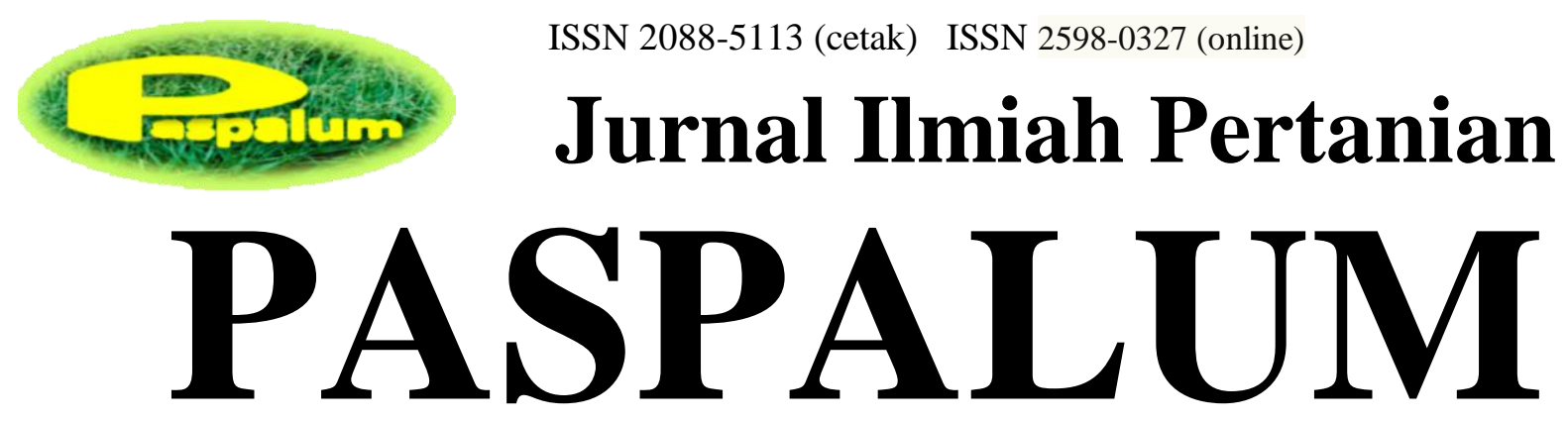

\author{
Vol. 7 No. 1 Bulan Maret Tahun 2019 \\ http://journal.unwim.ac.id/index.php/paspalum
}

\title{
Faktor-faktor yang Mempengaruhi Pendapatan Petani Beras Hitam Di Kecamatan Waluran Dan Ciemas
}

\author{
Dimyati dan Neneng Kartika Rini \\ Program Studi Agribisnis Fakultas Pertanain Universitas Muhammadiyah Sukabumi \\ dimiy05@gmail.com
}

Diterima tgl 6 September 2018 dan disetujui untuk diterbitkan tgl 15 Februari 2019

\begin{abstract}
The income referred to from this research is the results generated from the farming process. The study aimed to determine the effect of land area, seeds, fertilizers, pesticides, capital, labor, selling prices, production on the income of black rice farmers in the Districts of Waluran and Ciemas. The method used in this research is a quantitative descriptive method. Respondents related to this research were black rice farmers in Waluran and Ciemas subdistricts, as many as 81 respondents. Based on multiple linear calculations simultaneously the -7 variables significantly affected the income of black rice farmers, while partially from the - 7 variables only 4 influential variabl es include land area: fertilizer, seeds, production. While the capital, labor, and selling prices have no significant effect on the income of black rice farmers in Waluran and Ciemas sub-districts.
\end{abstract}

Keywords: Black Rice, Farmer Income, in the Districts of Waluran and Ciemas.

\begin{abstract}
Abstrak
Pendapatan yang dimaksud dari kajian ini adalah pendapatan yang dihasilkan dari proses bertani nya. Kajian ini bertujuan untuk mengetahui pengaruh luas lahan, benih, pupuk, pestisida, modal, tenaga kerja, harga jual, produksi terhadap pendapatan petani beras hitam di Kecamatan Waluran dan Ciemas. Adapun metode yang digunakan dalam ini yaitu metode deskriptif kuantitatif. Responden yang terkait dari peneian ini yaitu petani beras hitam di kecamatan Waluran dan Ciemas, sebanyak 81 responden. Berdasarkan hasil perhitungan linear berganda secara simultan ke-7 variabel (luas lahan, benih, pupuk, modal, tenaga kerja, harga jual dan produksi) tersebut berpengaruh terhadap pendapatan petani beras hitam, sedangkan secara parsial dari ke-7 variabel tersebut hanya 4 variabel yang berpengaruh diantaranya: luas lahan, pupuk, benih, produksi. Sedangakan modal, tenaga kerja, dan harga jual tidak berpengaruh terhadap pendapatan petani beras hitam di kecamatan Waluran dan Ciemas.

Kata kunci : Beras Hitam, Pendapatan Petani, Di Kecamatan Waluran dan Ciemas
\end{abstract}




\section{PENDAHULUAN}

Produksi padi Nasional pada saat ini masih mengandalkan pada lahan sawah, belum dapat memenuhi pangan beras oleh sebab itu produksi padi nasional secara berkelanjutan karena jumlah penduduk yang terus meningkat. Sedangkan lahan yang di tempati tidak bertambah serta terjadinya konversi lahan subur untuk pembangunan untuk non subsektor pertanian. Pengembangan padi gogo pada lahan kering merupakan alternatif strategis dalam rangka memenuhi kebutuhan pangan nasional, karena lahan kering berpotensi cukup luas dimana hasil produksi berkisar $6-7$ ton gabah Kering (Nazirah and Damanik, 2015).

Padi gogo merupakan salah satu komoditas pangan yang dapat berproduksi dilahan kering. Untuk pengembangan padi gogo di lahan kering belum termanfaatkan secara optimal, kemudian dapat menjadi solusi dalam mendukung ketahanan pangan.Pengembangan padi gogo merupakan salah satu upaya yang cukup startegis untuk mendukung peningkatan produksi beras nasional (Nurbaeti and Nurawan, 2009).

Beras hitam merupakan varietas lokal yang mengandung pigmen paling baik dibandingkan dengan beras lainnya, seperti beras putih, merah dan ketan hitam. Beras hitam memiliki rasa serta aroma yang baik seta penampilan yang spesifik dan unik bila dimasak nasi beras hitam ini warnanya menjadi pekat rasa dan aroma yang menggugah selera makan dan bermanfaat bagi kesehatan (Kristamtini et al., 2014; Mangiri et al., 2016). Tidak hanya itu saja harga beras hitam pun tergolong cukup mahal, sehingga mejadipeluang untuk para petani dalam memproduksi beras hitam lebih banyak. Keberagaman dalam penananaman tanaman pangan diharapkan para petani bisa mendapatkan hasil tambahan untuk memenuhi kebutuhan hidupnya. Di Kabupaten Sukabumi Kecamatan Waluran dan Ciemas merupakan salah satu Kecamatan yang mengembangkan beras hitam. Beras ini tergolong langka dan tidak terlalu dikenal oleh kebanyakan masyarakat. Padahal banyak sekali manfaat dan khasiat dalam beras hitam.

Kecamatan Waluran dan Ciemas pesifik daerah yang mengembangkan beras hitam, kemudian Kecamatan Waluran merupakan wilayah penunjang untuk pemasaran di kawasan Geopark Ciletuh. Faktor-faktor yang menentukan para petani menentukan usaha tani beras hitam yaitu ingin mendapatkan keuntungan yang lebih karena harga beras hitam lebih tinggi dibandingkan dengan harga beras lainnya, walaupun waktu menuju panennya relatif lebih lama (Suryana et al., 2017).

Usahatani beras hitam merupakan suatu jenis kegiatan pertanian rakyat yang diusahakan oleh petani dengan mengkombinasikan faktor-faktor produksi seperti, luas lahan, tenaga kerja, modal, teknologi dan pengelolaan yang ditujukan pada peningkatan produksi. Dengan peningkatan produksi ini diharapkan akan semakin meningkatkan kesejahteraan masyarakat petani.

Faktor-faktor yang memengaruhi beras hitam diantaranya lahan merupakan bagian penting, karena lahan merupakan tempat hidupnya tumbuhan, faktor lain yang juga berpangaruh adalah faktor tenaga kerja, faktor tenaga kerja sebagai sumberdaya manusia yang menjadi penggerak dalam seluruh produksi yang sedang dijalankan.Dengan permasalahan diatas, maka dibentuk kerangaka pemikiran pada Gambar 1.

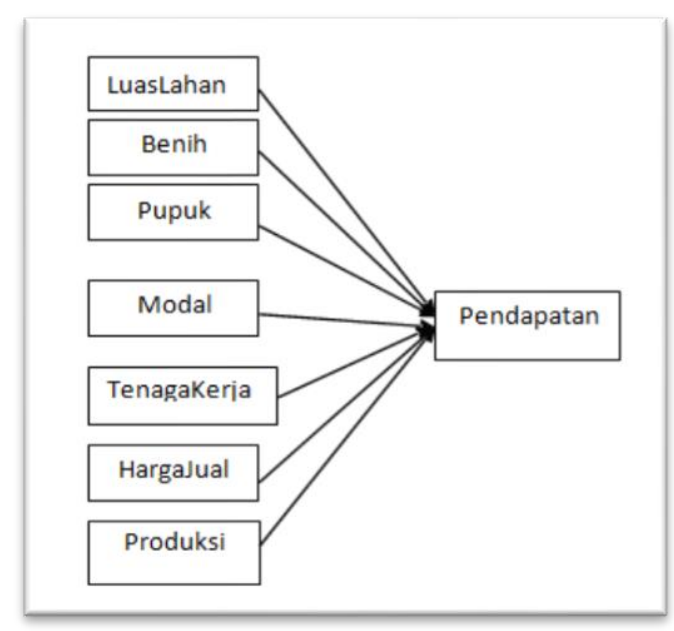

Gambar 1. Pengaruh Variable Proses Produksi terhadap Pendapatan Petani 


\section{METODE}

Metode yang digunakan yaitu metode survey. Penelitian ini dilakukan di Kecamatan Waluran dan Ciemas Kabupaten Sukabumi yaitu pada petani beras hitam. Penelitian ini dilakukan dengan cara Purposive Sampling, dimana seluruh petani beras hitam tidak memiliki kesempatan yang sama untuk menjadi responden dalam penelitian (Sugiyono, 2008). Responden dari penelitian merupakan petani beras hitam di Kecamatan Waluran dan Ciemas. Sebanyak 81 orang petani di kecamatan Waluran Dan Ciemas. Data yang diperoleh dari lapangan kemudian dianalissi menggunakan analisis ekonometrika, model regresi linear berganda dan data dioleh mengguanakan SPSS 23.

\section{PEMBAHASAN}

\section{Hasil Anailisis Regresi Linear Berganda Secara Simultan}

\begin{tabular}{|c|c|c|c|c|c|c|}
\hline \multicolumn{7}{|c|}{ ANOVA $^{\mathrm{a}}$} \\
\hline \multicolumn{2}{|c|}{ Model } & $\begin{array}{l}\text { Sum of } \\
\text { Squares }\end{array}$ & df & Mean Square & $\mathrm{F}$ & Sig. \\
\hline \multirow[t]{3}{*}{1} & Regression & $1,428 \mathrm{E}+15$ & 7 & $2,039 E+14$ & 25,186 &, $000^{b}$ \\
\hline & Residual & $5,911 \mathrm{E}+14$ & 73 & $8,097 \mathrm{E}+12$ & & \\
\hline & Total & $2,019 E+15$ & 80 & & & \\
\hline \multicolumn{7}{|c|}{ a. DependentVariable: PENDAPATAN } \\
\hline \multicolumn{7}{|c|}{$\begin{array}{l}\text { b. Predictors: (Constant), PRODUKSI, HARGA JUAL, TENAGA KERJA, MODAL, PUPUK, } \\
\text { BENIH, LUAS LAHAN }\end{array}$} \\
\hline
\end{tabular}

Gambar 2. Tabel Fh Regresi Linier

Dari analisis nilai Fhitung diperoleh sebesar 25,186 dengan tingkat signifikansi 0,000 lebih kecil dari 0,05 hal ini menunjukan bahwa luas lahan (1), benih (2), pupuk (3), modal (4), tenagaa kerja (5), harga jual (6), produksi (7) mempunyai pengaruh yang nyata terhadap pendapatan petani beras hitam. Dari Gambar 2 . menunjukan bahwa secara bersama-sama serentak (uji F) variabel bebas yaitu luas lahan, benih, pupuk, modal, tenagaa kerja, harga jual, produksi yaitu memiliki pengaruh yang positif terhadap variabel terikat pendapatan petani beras hitam di kecamatan Waluran dan Ciemas pada tingkat kepercayaan $\mathrm{a}=0,05 \%$ hal ini dapat dilihat dari nilai probabilitas signifikansi $\mathrm{F}$ sebesar 0,000 yang jauh lebih kecil dari 0,05 .

\section{Analisis Regresi Berganda Secara Parsial}

Pengujian secara parsila atau yang disebut dengan uji $t$ adalah untuk menguji seberapa besar pengaruh masing variabel bebas yang diteliti terhadap variabel terikat. Pada uji $t$ ini, nilai signifikansi masingmasing variabel dengan nilai probabilitasnya (sign. <0,05). Hasil pengolahan data faktorfaktok yang mempengaruhi pendapatan petani beras hitam.

Analisis pengaruh variabel bebas pada hasil regresi berganda faktor-faktor yang mempengaruhi pendapatan petani beras hitam. Pada taraf kepercayaan 95\% . disajikan pada Gambar 3. Variabel lahan memiliki nilai signifikansi $0,048<0,05$ artinya variabel lahan berpengaruh terhadap pendapatan petani beras hitam, nilai signifikansi ini kurang dari 0,05 namun memiliki nilai thitung -2010. variabel benih meiliki nilai signifikansi 0,00 artinya variabel benih berpengaruh terhadap pendapatan petani beras hitam karena nilai signifikansi ini kurang dari 0,05, dan memiliki niali $\mathrm{t}$ hitung sebesar 4199. Kemudian pupuk memiliki nilai signipikansi sebesar 0,016 artinya variabel pupuk tidak berpengaruh terhadap pendapatan petani beras hitang karena memiliki nilai signifikansi kurang dari 0,05 . Untuk variabel modal memiliki nilai siginifikansi 0,099> 0,05 artinya variabel modal tidak berpengaruh terhadap pendapatan petani karena memiliki nilai signifikansi lebih dari 0,05 , kemudian tenaga kerja memiliki nilai 0,338 variabel tenaga kerja tidak berpengaruh kerena memiliki nilai lebih besar dari pada 0,05. Harga juala memiliki nilai signifikansi 0,0886 variabel harga jual tidak berpengaruh karena memiliki nilai lebih dari pada 0,05 . Kemudian produksi memiliki nilai signifikansi 0,00 artinya variabel produksi berpengaruh nyata terhadap pendapatan petani karena memiliki nilai lebih kecil dari pada 0,05 . 
12|Paspalum: Jurnal Ilmiah Pertanian Volume 7 No 1 Maret 2019

\begin{tabular}{|c|c|c|c|c|c|c|c|c|c|c|c|c|c|}
\hline \multirow[b]{2}{*}{ Model } & & \multicolumn{2}{|c|}{ Unstansardzed Coefietients } & \multirow{2}{*}{\begin{tabular}{|c|}
$\begin{array}{c}\text { Stendardoso } \\
\text { Coefficents }\end{array}$ \\
Eeta
\end{tabular}} & \multirow[b]{2}{*}{1} & \multirow[b]{2}{*}{ Sig. } & \multicolumn{2}{|c|}{$95.0 \%$ confdence Intemal far B } & \multicolumn{3}{|c|}{ Comeanons } & \multicolumn{2}{|c|}{ Colinearity Statsits } \\
\hline & & $B$ & Str. Error & & & & Lowar Bound & Upper Bound & Zerb-arder & Partal & Part & Tolarance & WF \\
\hline 1 & [Constart] & .1028337900 & 3705107,625 & & .278 & 782 & 8412600,657 & 6355931,040 & & & & & \\
\hline & LLAS LAHAII & -8036189.061 & 3998186,394 & -463 & -2010 &, 048 & $-16004563,1$ & $-67815,068$ & .867 & -228 & -127 & .076 & 13,236 \\
\hline & BENH & 260118,395 & 66712,253 & 843 & 4.199 & .000 & 147161,066 & 413075,724 & .749 & 441 & .266 & 059 & 10,055 \\
\hline & PUPUK & .17108 .822 & 6952,642 & -318 & .2461 & .016 & $-39965,418$ & $.3252,226$ & .546 & $-2 \pi 7$ & , 156 & .240 & 4,173 \\
\hline & wook. & -.550 & .329 & -183 & -1.672 & .099 & $-1,205$ &, 106 & .560 & -192 & -106 & .336 & 2,875 \\
\hline & TEMGS KERJh & 87840.240 & 91158,842 & 094 & 964 & 338 & $-93839,071$ & 269519,551 & 477 & 112 &, 051 & .420 & 2,379 \\
\hline & HARGAJUAL & $.53,773$ & 372,697 & .009 & $\therefore 144$ & ,896 & 756,538 & 689,592 & .166 & .017 &., 009 & 939 & 1,072 \\
\hline & PRCOUKSI & 3971871 & 1071,021 &, 798 & 5576 &, 000 & 3837,209 & 6106,593 &, 773 & 546 & 353 & $13 \%$ & 5,111 \\
\hline
\end{tabular}

a. Debentert Variatie. PENDAPATA

Gambar 3. Tabel Hasil Regresi Berganda Secara Parsial

Dari hasil analisis diperoleh persamaan sebagai berikut:

$$
\begin{aligned}
Y=B & +X_{1}+X_{2}+X_{3}+X_{4}+X_{5}+X_{6}+X_{7} \\
Y= & -1028337,808-8036189,061 X_{1}+ \\
& 280118,395 X_{2}+17108,822 X_{3}- \\
& 550 X_{4}+87840,240 X_{5}-53,773 X_{6} \\
& +5971,872 X_{7}
\end{aligned}
$$

Keterangan :

$$
\begin{array}{ll}
\mathrm{Y}_{1} & =\text { Pendapatan Petani Beras Hitam } \\
\mathrm{X}_{1} & =\text { Luas Lahan } \\
\mathrm{X}_{2} & =\text { Benih } \\
\mathrm{X}_{3} & =\text { Pupuk } \\
\mathrm{X}_{4} & =\text { Modal } \\
\mathrm{X}_{5} & =\text { Tenaga Kerja } \\
\mathrm{X}_{6} & =\text { Harga Jual } \\
\mathrm{X}_{7} & =\text { Produksi }
\end{array}
$$

Analis faktor-faktor yang memepengaruhi pendapatan petani beras hitam (Y) sebagai variabel yang tida bebas. Luas lahan $\left(\mathrm{X}_{1}\right)$ benih $\left(\mathrm{X}_{2}\right)$ pupuk $\left(\mathrm{X}_{3}\right)$ modal $\left(\mathrm{X}_{4}\right)$ tenaga kerja $\left(\mathrm{X}_{5}\right)$ harga jual $\left(\mathrm{X}_{6}\right)$ dan produksi $\left(\mathrm{X}_{7}\right)$ sebagai variabel bebas. Berdasarkan hasil regresi nilai koevisien variable luas lahan Artinya jika luas lahan di perluas maka pendapatan petani akan meningkat sebesar $\quad-8036189,061$. Sedangkan nilai koefisien variabel benih 280118,395 artinya apabila jumlah benih ditingkatkan maka pendapatan petani beras hitam akan meningkat sebesar 280118,395. Koefisien Variabel pupuk -17108,822 artinya jika pemakaiyan pupuk ditingkatkan maka pendapatan petani akan meningkat sebesar 17108,822 . Koefisen variabel modal 0,550 artinya jika modal ditingkatkan maka pendapatan petani akan menurun sebesar 0,550. Koefisien variabel tenaga kerja 87840,240 artinya jika tenaga kerja ditingkatkan maka pendapatan petani akan menurun sebesar 87840,240. Koefisien variabel harga jual 53,773 artinya harga jual tidak berpengaruh terhadap pendapatan petani beras hitam. Koefisien variable produksi 5971,871 artinya jika produksi ditingkatkan maka pendapatan petani beras hitam akan meningkat sebesar 5971,871.

\section{Koefisien Determinasi}

Dari hasil analisis regresi berganda diperoleh nilai $\mathrm{R}^{2}$ sebesar 0,841 dan $\mathrm{R}$ squere 0,707. Hasil pendapatan petani

\begin{tabular}{|c|c|c|c|c|c|c|c|c|c|c|}
\hline \multirow[b]{2}{*}{ Hodel } & \multirow[b]{2}{*}{$R$} & \multirow[b]{2}{*}{ RSquare } & \multirow[b]{2}{*}{$\begin{array}{l}\text { Ajusted R } \\
\text { Souale }\end{array}$} & \multirow[b]{2}{*}{$\begin{array}{l}\text { Siv Erotorof } \\
\text { the Esinite }\end{array}$} & \multicolumn{5}{|c|}{ Changes Stastics } & \multirow[b]{2}{*}{$\begin{array}{l}\text { Dutin. } \\
\text { Wasison }\end{array}$} \\
\hline & & & & & $\begin{array}{l}\text { RSpure } \\
\text { Change }\end{array}$ & FChange & th & th? & $\begin{array}{l}\text { Sigh } \\
\text { Change }\end{array}$ & \\
\hline 1 & $.841^{\circ}$ & 707 & 679 & 286499,99 & 707 & 25,186 & $?$ & 73 & 000 & 2083 \\
\hline
\end{tabular}
beras hitam $70,7 \%$ dipengaruhi oleh luas lahan, benih, pupuk, modal, tenaga kerja, harga jual, produksi beras hitam sedangkan $29,3 \%$ dipengaruhi variabel lain yang tida ada dalam penelitian ini. Dengan demikian terbukti bahwa variabel-variabel bebas yang terdiri dari luas lahan, benih, pupuk, modal, tenaga kerja, harga jual, produksi beras hitam secara bersama- sama mempengaruhi secara signifikan terhadap pendapatan petani beras hitam.

IModel Summary

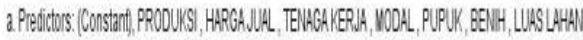

b. Dependertllariald: PEIOPPTTW

Gambar 4. Tabel Koefisien Determinasi 


\section{Pendapatan Petani Beras Hitam}

Pendapatan usaha tani merupakan salah satu penerimaan yang diperoleh petani pada saat kegiatan usaha taninya. Hasil penelitian menunjukan bahwa ratarata pendapatan petani beras hitam adalah sebesar Rp. 10.512918,25 perhektar pertahun. Secara parsial analisis linear berganda untuk faktor-faktor yang memepengaruhi pendapatan petani beras hitam di kecamatan Waluran dan Ciemas adalah sebagai berikut:

\section{Luas lahan $\left(\mathbf{X}_{1}\right)$}

Faktor luas lahan $\left(\mathrm{X}_{1}\right)$ memepengaruhi pendapatan petani beras hitam karaena nilai signifikansi 0,048 lebih kecil dari pada 0,05 pada taraf kepercayaan $95 \%$ yang dapat dilihat pada Gambar 2. sehingga luas lahan berpengaruh nyata terhadap pendapatan petani beras hitam di Kecamatan Waluran dan Ciemas. Selanjutnya dari persamaan regresi berganda, diperoleh hasil koefisien variabel luas lahan sebesar -8036189,061 hal ini berarti jika luas lahan bertambah maka tingkat pendapatan akan menurun sebesar 8036189,061. Menurut Rumintjap and Muis (2014) apabila luas lahan semakin besar maka semakin besar pula jumlah produksi dan secara langsung akan meningkatkan pendapatan petani beras hitam di kecamatan Waluran dan Ciemas.

\section{Benih $\left(\mathbf{X}_{2}\right)$}

Faktor benih $\left(\mathrm{X}_{2}\right)$ mempengaruhi pendapatan petani beras hitam karena memiliki nilai signifikansi 0,00 lebih kecil dari 0,05 pada taraf kepercayaan $95 \%$ bila dilihat pada Gambar 3. Variable benih berpengaruh positif terhadap pendapatan petani beras hitam. Nilai koefisien variabel benih sebesar 265629,880 artinya jika penggunaan benih meningkat maka akan meningkatkan pendapatan petani. Hal ini selaras dengan pernyataaan Rumintjap and Muis (2014) bahwa peningkatan benih akan meningkatakan jumlah tanaman dan produksi padi sehingga akan meningkatkan pendapatan petani. Kenyataan di lapanagn para petani beras hitam di kecamatan waluran di ciemas menggunakan varietas lokal yang bibitkan oleh petani. Hal ini diakibatkan karna ketidak tersediaan benih varietas unggul serta belum tersedinya benih /bibit unggul disamping itu karna sudah menjadi kebiasan para petani memebibitkan benihnya sendiri dengan cara menyisakan sebagaian hasil panennya untuk dijadikan benih. Untuk pembenihan sendiri para petani masih menggunakan varietas lokal dengan rata-rata pengguanaan benih $25 \mathrm{~kg}$.

\section{Pupuk $\left(\mathbf{X}_{\mathbf{3}}\right)$}

Faktor pupuk $\left(\mathrm{X}_{3}\right)$ berpengaruh secara nyata terhadap pendapatan petani beras hitam hal itu bisa dibuktikan bahwa pupuk memiliki nilai signifikasi 0,00 artinya lebih kecil dari pada 0,05 dengan taraf kepercayaan $95 \%$. Variabel pupuk secara posistip berpengaruh terhadap pendapatan petani beras hitam. Adapun nilai dari koefisien variabel pupuk sebesar 16746,319 artinya jika pemakaian pupuk ditingkatkan maka jumlah pendapatan akan meningkat sebesar 16746,319. Rata-rata pengeluran untuk biaya pemupukan para petani mengeluarkan sebesar Rp 423.451 biasanya para petani melakukan pemupukan 2 kali dalam satu kali musim tanam yaitu dengan cara ditebar. Hal ini diduga karena pupuk yang diberikan oleh para petani mencukupi kebutuhan unsur hara yang dibutuhkan oleh tanaman itu sendiri.

\section{Modal $\left(\mathbf{X}_{4}\right)$}

Berdasarkan perhitungan regresi linear berganda koefisien modal memiliki nilai sebesar -564. Dengan taraf kepercayaan 95\% $(0,92>0,05)$ Artinya variabel modal berpengaruh namun tidak nyata terhadap pendapatan petani beras hitam di Kecamatan Waluran dan Ciemas koefisien variabel menunjukan nilai negatip artinya apabila modal ditingkatkan maka pendapatan akan semakin kecil. Menurut data di lapangan modal yang dikeluarkan oleh petani hanya seadanya saja untuk pengadaan modal biasanya para petani menyisakan hasil yang dijual untuk modal penanaman dari mulai mengolah lahan sampai panen. Modal yang dikeluarkan oleh petani padi hitam yaitu untuk membayar tenaga kerja, membeli pupuk. Modal yang cukup besar tersebut menyebabkan produksi padi hitam meningkat, melihat dari hasil produksi 
yang signifikan. Namun meskipun produksi cukup tinggi, harga dari padi hitam ini cukup rendah, dalam menjalankan proses usaha taninya para petani jarang sekali menggunakan biaya seperti biaya untuk perwatan seperti pemberian vitamin untuk beras hitam itu sendiri petani hanya mengambil hasilnya saja saat panen tiba.

\section{Tenaga kerja $\left(\mathbf{X}_{5}\right)$}

Variabel tenaga kerja memiliki nilai sebesar 27795,561 variabel tenaga kerja tidak signifikan dengan taraf kepercayaan $95 \%(0,611>0,05)$ tenaga kerja berpengaruh secara positif namun tidak nyata terhadap pendapatan petani beras hitam di kecamatan Waluran dan Ciemas. Hal yang menjadi penyebab dari kecilnya penggunanaan tenga kerja diakibatkan karena petani menghemat dalam menggunakan tenaga kerja dan kebanyakan petani di kecamatan waluran dan ciemas menggunakan sebagain tenaga kerja dari keluarga atau di garap sendiri sebagaian kecilnya tenaga kerja dari luar keluarga sehingga kinerja dari tenaga kerja kurang maksimal. Hal ini sesuai yang dikemukan oleh Rumintjap and Muis (2014) bahwa kemungkinan yang menjadi penyebabnya, karena kecilnya penggunaan tenaga kerja, serta pengguanaan tenaga kerja yang belom berpengalaman atau masih pemula shingga akan menurunkan produksi secara tidak langsung pendapatan pun akan mengalami penurunan.

\section{Harga jual $\left(\mathbf{X}_{6}\right)$}

Dari hasil analasis regresi linear berganda harga jual terhadap pendapatan petani diperoleh nilai sebesar $-53,497$ harga jual tidak signifikan dengan taraf kepercayaan $95 \%(0,887>0,05)$ artinya harga jual berpengaruh namun secara negatif terhadap pendapatan petani beras hitam di kecamatan Wauran dan Ciemas hal ini disebabkan oleh hampir semua petani padi hitam di kecamatan Waluran dan Ciemas menjual hasil panennya dalam bentuk gabah rata-rata harga Rp.10.000 ditingkat petani penjualan hasil panen tersebut dalam gabah tersebut mengakibatkan pendapatan petani tidak terlalu besar dilihat dari harga produksi yang mereka keluarkan. Jika petani melakukan proses pasca panen dengan merubah bentuk gabah menjadi beras maka akan meningkatkan nilai tambah padi hitam tersebut. Harga padi hitam yang sudah jadi beras di kecamatan Waluran dan Ciemas Rp 15.000 harga tersebut cukup berbeda jauh dengan haga gabah yang hanya $\mathrm{Rp}$ 10000 dengan melalaui proses pasca panen dengan mengubah gabah menjadi beras menciptakan nilai tambah berupa harga yang cukup tinggi sehingga pendapatan petani dapat meningkat.

\section{Produksi $\left(\mathbf{X}_{7}\right)$}

Berdasarkan perhitungan regresi linear berganda, koefisien produksi $\left(\mathrm{X}_{8}\right)$ mempengaruhi pendapatan petani beras hitam karena memiliki nilai signifikansi 0,00 lebih kecil dari 0,05 dengan taraf kepercayaan $95 \%$ yang dapat dilihat pada tabel 5 dengan demikian variabel produksi berpengaruh secara nyata terhadap pendapatan petani beras hitam di kecamatan Waluran dan Ciemas, selanjutnya dari persamaan regresi berganda, diperoleh hasil koefisien variabel produksi sebesar 6013,843 ini berarti jika produksi ditingkatkan maka pendapatan petani pun akan meningkat sebesar 6013,843 . Rata-rata produksi padi hitam di kecamatan waluran dan ciemas dengan luas lahan yang pariativ sebasr $1.120 \mathrm{~kg}$ dengan peroduktivitas lahan per hektar 6 ton. Produksi tersebut bisa dikatakan cukup besar sehingga dengan besarnya produksi para petani bisa meningkatkan volume penjualan, hal ini akan meningkatkan pendapatan petani.

\section{KESIMPULAN}

Berdasarkan hasil perhitungan linear berganda secara simultan ke-7 variabel (luas lahan, benih, pupuk, modal, tenaga kerja, harga jual dan produksi) tersebut berpengaruh nyata terhadap pendapatan petani beras hitam, sedangkan secara parsial dari ke-7 variabel tersebut hanya 4 variabel yang berpengaruh diantaranya: luas lahan, pupuk, benih, produksi. Sedangkan modal, tenaga kerja, dan harga jual dan pestisida tidak berpengaruh 
nyata terhadap pendapatan petani beras hitam di kecamatan Waluran dan Ciemas.

Perlu adanya penelitian lebih lanjut tentang beras hitam ini terutama di bidang budidaya beras hitam agar masyarakat lebih mengetahui cara yang baik dan benar dalam memelihara dan mengahasilkan padi hitam yang baik dari kuantitas dan kualitasnya. Kemudian untuk modal harus lebih ditingkatkan karna modal memiliki peranan penting, harga jual dengan mentapkan harga yang tetap ditingkat petani dan utuk tenaga kerja lebih ditingkatkan. Sehingga akan berdampak pada peningkatan pendapatan petani beras hitam di kecamatan Waluran dan Ciemas.

\section{DAFTAR PUSTAKA}

Kristamtini, Taryono, P. Basunanda, and R.H. Murti. 2014. Beras Hitam Sumber Antosionin Dan Prospeknya Sebagai Pangan Fungsional. J. Penelit. dan Pengemb. Pertan. 33(1): 17-24. doi: http://dx.doi.org/10.21082/jp3.v33n1.201 4.p17-24.

Mangiri, J., N. Mayulu, and S.E.S.

Kawengian. 2016. Gambaran Kandungan Zat Gizi Pada Beras Hitam (Oryza sativa L.) Kultivar Pare Ambo Sulawesi Selatan. e-Biomedik 4(1). https://ejournal.unsrat.ac.id/index.php/ebi omedik/article/view/11050.

Nazirah, L., and B.S.J. Damanik. 2015. Pertumbuhan Dan Hasil Tiga Varietas Padi Gogo Pada Perlakuan Pemupukan. J. Foratek 10: 54-60. jurnal.unsyiah.ac.id/floratek/article/down load/2329/2215.

Nurbaeti, B., and A. Nurawan. 2009. Petunjuk Teknis Pengelolaan Tanaman Dan Sumberdaya Terpadu (B Irawan, Ed.). Balai Pengkajian Teknologi Pertanian (BPTP) Jawa Barat Balai Besar Pengkajian dan Pengembangan Teknologi Pertanian Badan Penelitian dan Pengembangan Pertanian Departemen Pertanian, Lembang.

Rumintjap, V., and A. Muis. 2014. Analisis

Produksi Dan Pendapatan Usahatani Padi Sawah Di Desa Pandere Kecamatan Gumbasa Kabupaten Sigi Provinsi Sulawesi Tengah. e-J.Agrotekbis 2(3): 309-316. http://jurnal.untad.ac.id/jurnal/index.php/ Agrotekbis/article/view/3537.

Sugiyono. 2008. Metode Penelitian

Kuantitatif, Kualitatif dan R\&D.

Alfabeta, Bandung.

Suryana, D.H. Sujaya, and M.N. Yusuf. 2017. Analisis Usahatani Padi Hitam Organik

(Oryza sativa L.) (Studi Kasus

Kecamatan Padaherang Kabupaten

Pangandaran). J. Ilm. Mhs. Agroinfo

Galuh 4(1): 651-657.

https://jurnal.unigal.ac.id/index.php/agroi nfogaluh/article/view/1613. 